\title{
Corrigendum: Systematic pan-cancer analysis of tumour purity
}

Dvir Aran, Marina Sirota \& Atul J. Butte

Nature Communications 6:8971 doi: 10.1038/ncomms9971 (2015); Published 4 Dec 2015; Updated 5 Feb 2016

In the Results section of this Article, haematoxylin and eosin staining data from the TCGA repository are incorrectly referred to as immunohistochemistry data. All references to 'immunohistochemistry' or 'IHC' should read 'haematoxylin and eosin staining' or 'H\&E staining', respectively.

(c) This work is licensed under a Creative Commons Attribution 4.0 International License. The images or other third party material in this article are included in the article's Creative Commons license, unless indicated otherwise in the credit line; if the material is not included under the Creative Commons license, users will need to obtain permission from the license holder to reproduce the material. To view a copy of this license, visit http://creativecommons.org/licenses/by/4.0/ 